The Editor, The Fournal of Glaciology

SiR,

\author{
Glaciers of Fan Mayen
}

Since the last issue of the fournal of Glaciology was published, my attention has been drawn to Professor R. F. Flint's excellent description of Sørbreen (South Glacier) of Jan Mayen in Miss Louise A. Boyd's The Coast of Northeast Greenland. This detailed account was written in 1938 from observations made in the summer of 1937 . I would like to point to two features mentioned in this, which I failed to observe in 1938 . West of Sørbreen near its snout, Flint records a striated rock surface and other indications of early extension in that direction and also an old lateral moraine north of Kapp Fishburn (Cape Fishburn) east of the outer lateral moraine of my description. This evidence suggests that Sørbreen also suffered the earlier phase of retreat that Kerckhoffbreen (Kerckhoff Glacier) and certain other glaciers underwent.

Lt. Bobrik von Boldva noticed the absence of any mention of Sørbreen in a seventeenth-century Dutch description of Jan Mayen. Flint recalls this and regards it as furnishing "a possible minimum time for the entire series of South Glacier deposits." However, von Boldva shows how unreliable the Dutch accounts are with reference to other glaciers on the island. Moreover, William Scoresby, Jnr., failed to describe Sørbreen at the beginning of the nineteenth century. Thus this negative argument can hardly carry much weight.

It is of interest also to hear from Professor P. L. Mercanton, of the Commission helvétique des Glaciers, that he measured the rate of movement of Sørbreen in 1921 at $0.5 \mathrm{~cm}$. a day. This slow speed agrees with the Austrian measurement in 1882 and the retreat phenomena of the glacier.

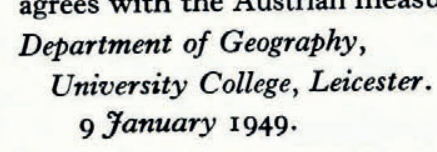

J. N. JeNNINGS

Sir,

\title{
Boulder Clay Fabric
}

As none of the reviews (including that in Vol. 1 , No. 4 of the Fournal of Glaciology) of Professor R. F. Flint's invaluable new book Glacial Geology and the Pleistocene Epoch (New York, 1947) have drawn attention to its tacit acceptance of the new "lodgement" hypothesis of boulder clay formation I should like to make the following comments.

The hypothesis that boulder clay has mostly accumulated during the active movement of an ice sheet was introduced by C. D. Holmes (Till fabric, Bulletin of the Geological Society of America, Vol. 52, 194I, pp. 1299-354) to account for the differential orientation of stones of various shapes in the boulder clay sections investigated by him in New York State. So far as I can discover there has been no further important published work bearing on this problem of till fabric. In view of the fact that the statistical validity of the results for some of the smaller shape-groups may be questioned, and that there is some evidence of bias (unconscious bias in favour of round numbers in taking readings) which affects some of the results, it seems premature to accept Holmes's findings with regard to preferred orientations, let alone the resulting theory.

However, C. D. Holmes's work is valuable pioneering in a field which has been seriously neglected in this country. There is no doubt that a clear understanding of the way in which boulder clay is formed will make possible big advances in Pleistocene stratigraphy. Two lines of inquiry are open : (i) observation on existing ice sheets, (ii) the study of till fabric.

With regard to the latter it is clear that any clue to the parallel orientation of stones of particular shapes may arise in one or more of the following ways: (a) orientation during deposition beneath flowing ice as envisaged by Holmes, (b) orientation within the flowing ice preserved on the melting of the ice, (c) orientation during settling of the moraine on the melting of the ice. It is clear that the mode of melting of the ice must affect structures due to (b) and (c).

In Europe it has generally been assumed that the settling of the stones on the melting of an ice sheet has tended to produce lack of structure. To account for the preservation of structures inherited from the ice Carruthers's theory of bottom melting is designed to reduce the importance of settling. German authors tend to meet the same problem by envisaging ice to be so encumbered with moraine that movement on settling has been limited by lack'of elbow-room. Such ice must have become stagnant before melting. However, it should surely be borne in mind that the settling process may not have been purely negative and destructive, but may have had a positive effect and produced its own structure. 
It would seem that a great deal more exact observation of boulder clay fabric is called for. Careful measurements on the lines of C. D. Holmes's work may yield very valuable results.

Marischal College, Aberdeen.

Scott Simpson

6 fanuary 1949.

The Editor,

The Fournal of Glaciology

Sir,

The Snow Survey of Great Britain

If I may briefly reply to Mr. Hawke's letter in the last issue of the Fournal of Glaciology, I should like again to emphasize the need for caution in drawing generalizations on snowfall for the entire country from a limited number of stations. This particularly applies to comparisons with the past, for which, as Mr. Hawke himself admits, data gradually become more meagre and less reliable. The Survey after all has to work, so to speak, on a grid, in which must inevitably occur large meshes of unrepresented country very significant in a land of complex physical relief like Great Britain.

Take the very month which Mr. Hawke quotes, namely December 1890 , which was so rigorous in the South, especially round Oxford. I am old enough to remember as a child that very severe season when a large meadow at the back of my home in a London suburb was continuously white from 27 November to 21 January $1890-91$. From this personal experience taken in conjunction with all I heard at the time about the prevailing conditions and read about them in the ensuing years I cannot but feel that in this particular case the three stations quoted by Mr. Hawke as having had thirty-one days of snow cover in December 1890 , namely, New Radnor (Wales), Walthamstow (Essex), and Diss (Norfolk), were much more representative of Southern England as a whole than the five others quoted by him with considerably fewer days, namely Babbacombe (Devon), Ross (Hereford), Rotherby Hall (Leicester), Derby and Salisbury. Mr. Hawke quotes Babbacombe as having had only four days of snow cover but even if this figure is reliable and representative of any considerable stretch of this much indented coast $I$ heard a very different account from a family of cousins living inland in Devonshire. They spoke of being continuously under snow for several weeks, thus supporting my own experience in Middlesex, with only a clear month in February before the onset of the famous blizzard of 9 March in that part of the country. Northward of Lancashire and Yorkshire the season was milder and there was little snow in Scotland, as Mr. Hawke observes,
except at high levels.

I 3 Christchurch Hill,

Hampstead, N.W.3.

L. C. W. Bonacina

24 April I949.

SIR,

On being invited to cite documentary evidence for his assertion that "in $1890-91$ most of England was continuously under snow from 27 November to 21 January," Mr. Bonacina tells us merely of a large meadow at the back of his boyhood home in a London suburb which, according to his recollection, remained white over exactly that period. And this after he has enjoined caution in drawing generalizations on snowfall from a limited number of stations. All regional climatic studies depend on "a grid in which must inevitably occur large meshes of unrepresented country"; outside Utopia we cannot have an observing post for every square mile. Official summaries and averages of rainfall, sunshine, temperature and other elements are necessarily thus derived. Is not the method equally valid for the Snow Survey with its copious data from a well-distributed host of observers, plus the returns courteously supplied to us by the Meteorological Office?

Ivinglea, Dagnall. 28 April 1949.

E. L. HAWKE 